\title{
ПРОФЕСІЙНЕ САМОВДОСКОНАЛЕННЯ МАЙБУТНІХ УЧИТЕЛІВ ІНОЗЕМНОЇ МОВИ У ПРОЦЕСІ ДИСТАНЦЙНОГО НАВЧАННЯ
}

\author{
Пінчук Л. М. \\ кандидат педагогічних наук, \\ дочент кафедри викладання другої іноземної мови \\ Запорізький національний університет \\ вул. Жуковського, 66, Запоріжжя, Украӥна \\ orcid.org/0000-0001-6968-5122 \\ larisapinchuk2000@gmail.com
}

\author{
Ключові слова: \\ професійна підготовка \\ студентів, ключові \\ компетентності, онлайн- \\ навчання, мотивачія, \\ інформаційно-комунікаційна \\ компетентність.
}

У статті розглядається проблема підвищення рівня професійної компетенції, розвитку професійно-значущих якостей відповідно до соціальних вимог, умов професійної діяльності і власної програми розвитку майбутніх учителів іноземної мови у процесі дистанційного навчання. Виділено цифрову компетентність як одну 3 ключових компетенцій. Узагальнено досвід онлайн-занять 3 англійської мови 3 використанням навчальних інтернет-ресурсів, визначено особливості професійного самовдосконалення майбутніх вчителів іноземної мови в процесі формування цифрової компетентності під час проведення онлайн-занять 3 англійської мови 3 використанням різних навчальних платформ (Moodle, Zoom, Skype), навчальних курсів (FutureLearn, Coursera), інтернет-ресурсів (Hotlist, Treasure Hunt, Subject Sampler, Multimedia Scrapbook, Webquest).

Розглянуто основні функції інформаційно-комунікаційних технологій, які використовуються в навчальному процесі. Визначено особливості формування цифрової компетентності майбутніх учителів іноземної мови; розглянуто можливості вивчення іноземних мов за допомогою інформаційно-комунікаційних технологій.

Виокремлено переваги дистанційного навчання, а саме: навчання в індивідуальному темпі в комфортних умовах, гнучкий режим, можливості для студентів планувати час, місце та тривалість занять та обирати швидкість засвоєння матеріалу залежно від їх особистих потреб. Зазначено деякі недоліки дистанційної форми навчання для окремих студентів у період вимушеної ізоляції під час карантину: відсутність особистого спілкування між студентами і викладачами, якщо студент не мав змоги перейти в режим відеозв'язку; неготовність до суворої самодисципліни, самостійності та самоконтролю в процесі онлайннавчання; відсутність доступу до якісного інтернету. Успішне онлайннавчання вимагає сильної мотивації та самоорганізації студентів, розвитку таких особистісних якостей, як відповідальність, уважність, вміння працювати самостійно, систематично та наполегливо. Розвиток цифрової компетентності в майбутніх учителів іноземної мови є однією зі складових частин їхнього професійного самовдосконалення. 


\title{
PROFESSIONAL SELF-IMPROVEMENT OF THE FUTURE FOREIGN LANGUAGE TEACHERS IN THE PROCESS OF DISTANCE EDUCATION
}

\author{
Pinchuk L. M. \\ Candidate of Pedagogical Sciences, \\ Associate Professor at the Department of Teaching Second Foreign Language \\ Zaporizhzhia National University \\ Zhukovskoho str., 66, Zaporizhzhia, Ukraine \\ orcid.org/0000-0001-6968-5122 \\ larisapinchuk2000@gmail.com
}

\begin{abstract}
Key words:
professional training of students, key competences, distance education, motivation, digital competence.
\end{abstract}

\begin{abstract}
The article deals with the problem of increasing the level of the professional competence, the development of professionally significant qualities in accordance with the social requirements, conditions of professional activity of the future foreign language teachers in the process of distance learning. Digital competence as one of the key competencies is highlighted. The experience of online classes in English and the features of the professional selfimprovement of the future foreign language teachers in the process of forming digital competence during online English classes with the use of the various platforms (Moodle, Zoom, Skype), training courses (FutureLearn, Coursera), Internet resources (Hotlist, Treasure Hunt, Subject Sampler, Multimedia Scrapbook, Webquest) is summarized. The main functions of information and communication technologies used in the educational process are considered. Peculiarities of digital competence formation of the foreign language teachers are determined. Possibilities of studying foreign languages with the help of information and communication technologies are considered. The advantages of distance learning, such as studying at an individual pace in a comfortable environment, flexible mode, opportunities for students to plan the time, place and duration of the classes and choosing the speed of learning depending on their personal needs are highlighted. Some disadvantages of distance learning for individual students during the isolation period, such as lack of personal communication between students and teachers in cases where the students did not have the opportunity to switch to video mode; unwillingness to strict selfdiscipline, independence and self-control in the process of online learning; lack of access to quality Internet are noted. Successful online learning requires students' strong motivation and self-organization, the development of such personal qualities as responsibility, attentiveness, the ability to work independently, systematically and persistently. The development of the digital competence in the future foreign language teachers is one of the key components of their professional self-improvement.
\end{abstract}

Постановка проблеми. Необхідність модернізації усіх сфер діяльності українського суспільства, кардинальні зміни, що відбуваються на ринку праці, дефіцит кваліфікованих кадрів, які б відповідали сучасним вимогам, поява нових компетенцій привели до виникнення викликів, на які має відповісти сучасна освіта. Інформаційний вибух виявив проблеми і недоліки традиційної системи викладання, орієнтованої на передачу знань, та заміни концепції «знаннєвого» підходу концепцією компетентнісного підходу. Цифровий контент професійної сфери, розвиток інформацій- них технологій висувають підвищені вимоги до компетентностей випускників університетів. Розбудова національної системи вищої освіти в умовах кардинальних змін в усіх сферах суспільного життя, історичних викликів XXI століття, інтеграційних і глобалізаційних процесів відповідності до «Національної стратегії розвитку освіти в Україні на період до 2021 року» спрямована на формування і розвиток інтелектуального, культурного, духовно-морального потенціалу особистості, їі самостійності, самодостатності, творчої активності. Національна стратегія передбачає 
розроблення стандартів вищої освіти, зорієнтованих на компетентнісний підхід [3].

Проблеми формування творчої особистості педагога, його професійного становлення і самовдосконалення завжди були в центрі уваги таких науковців, як А.М. Алексюк, Я.Я. Болюбаш, I.M. Дичківська, M.O. Євтух, I.А. Зязюн, А.І. Кузьмінський, Н.Г. Ничкало, О.М. Пєхота, О.I. Пометун, М.М. Фіцула та ін. Застосування інформаційно-комунікаційних технологій у навчальному процесі з метою підвищення якості професійної підготовки студентів стало предметом дослідження таких науковців, як C.I. Архангельський, М.I. Жалдак, О.П. Значенко, Г.О. Козлакова, В.І. Луговий, Ж.В. Таланова.

Професійне самовдосконалення - свідомий, цілеспрямований процес підвищення рівня власної професійної компетенції і розвитку професійно значущих якостей відповідно до соціальних вимог, умов професійної діяльності і власної програми розвитку. Професійне самовдосконалення відбувається у вигляді двох взаємопов'язаних форм - самоосвіти і самовиховання, тобто бажання майбутнього фахівця вдосконалювати свої знання, уміння і навички, щоб досягти високого рівня професійної компетентності, i бажання удосконалювати свої особистісні риси характеру, виховувати, наприклад, такі якості, як відповідальність, організованість, самодисципліна, i усувати негативні риси, які заважають досягти успіху в житті, такі як лінощі, заздрість, неорганізованість, невміння доводити до кінця розпочату справу і т.п. [4, с. 51].

Нова парадигма освіти передбачає формування і розвиток ключових компетентностей, які $€$ вкрай важливими для досягнення успіху у професійному і особистому житті людей, які вміють навчатися впродовж життя, критично мислити, ставити цілі та досягати їх, працювати в команді, спілкуватися в багатокультурному середовищі та володіти іншими сучасними вміннями. Цифрова компетентність (digital competence) визначена Радою Європи однією 3 пріоритетних [6].

Мета статті. Цифрова модернізація освіти безпосередньо пов'язана із впровадженням сучасних освітніх технологій, у тому числі інформаційних, що дають змогу розвивати як загальні компетенції, необхідні випускникам вишів для успішної адаптації на ринку праці, так і специфічні компетенції (мовні, комунікативні, соціолінгвістичні), головна мета яких - уміння комунікувати в соціальному, культурному та професійному середовищі.

Водночас можливості більш грунтовної роботи на освітніх платформах Moodle, Zoom, Skype, Google Classroom та інших, на жаль, недооцінювались у звичному режимі навчання іноземної мови. Але цього року українські універ- ситети під час навчального семестру були закриті на карантин майже три місяці. Очевидно, що це стало своєрідним викликом для багатьох освітян, особливо складно було переходити на дистанційний режим роботи в перші тижні. I викладачі, i студенти виявилися неготовими швидко «пірнути» у віртуальне навчання. Але поступово, крок за кроком, усі звикли до онлайн-занять на освітніх платформах Zoom, Skype, Moodle, Google Classroom та інших.

Мета статті - узагальнити досвід онлайн-занять 3 англійської мови $з$ використанням навчальних інтернет-ресурсів і визначити особливості професійного самовдосконалення майбутніх вчителів іноземної мови в процесі формування цифрової компетентності (digital competence).

Виклад основного матеріалу дослідження. Онлайн-навчання, або дистанційне навчання, - це форма організації навчального процесу, яка передбачає переважне використання комп'ютерних технологій і мережі Інтернет у процесі навчання. «Протягом останнього десятиріччя дистанційне навчання стало одним із найважливіших елементів системи вищої освіти промислово розвинених країн. 3 одного боку, це зумовлено бурхливим розвитком інформаційних технологій, з іншого політикою урядів цих країн у галузі освіти, їхнім прагненням зробити навчання та освіту будьякого рівня максимально доступними для всіх верств населення» $[1$, с. 92].

Перші університети 3 дистанційною формою навчання, так звані відкриті університети, з'явились в Англії у середині XX сторіччя у зв'язку з розвитком освітніх технологій. За час існування Відкритого Університету Великої Британії, заснованого у 1969 році, вищу освіту отримали понад 2 мільйони студентів. Відкриті університети давали змогу вибирати програми навчання, викладачів вибраних курсів, відповідний графік навчання і форми роботи незалежно від місця проживання студента. Університети надавали доступ до інформаційних ресурсів і змогу навчатися за індивідуальним планом без обмеження терміну навчання. Основною технологією навчання стала технологія дистанційного навчання.

Серед переваг навчання за дистанційною формою можна виділити, перш за все, те, що студенти мають змогу навчатися будь-де і будь-коли, незалежно від віку, рівня підготовки і віддаленості від центрів освіти. В основі навчального процесу самостійна, наполеглива, цілеспрямована робота студентів, які мають широкі можливості вибору дисциплін і технологій навчання. Університети надають інформаційну підтримку процесу навчання, змогу користуватися навчальними матеріалами з вибраної дисципліни, які зберігаються на інформаційних серверах і в базах даних. Універ- 
ситети дають змогу навчатися за індивідуальною програмою з урахуванням інтересів і потреб студента, здійснюють постійний контроль за рівнем засвоєння навчального матеріалу в рамках вибраного навчального курсу. Структурними компонентами дистанційного навчання є навчальний центр, викладачі-консультанти, інформаційні ресурси у вигляді навчальних курсів, довідкових матеріалів, а також засоби забезпечення технології дистанційної освіти.

Великою перевагою відкритих університетів стала доступність навчання для широких верств населення, адже навчання за дистанційною формою коштувало набагато дешевше, ніж у традиційних університетах. До того ж студентам дистанційної форми навчання не потрібно двічі на рік приїжджати в університет і здавати екзаменаційну сесію, адже вони навчаються віртуально, за допомогою ресурсів мережі Інтернет, здійснюють інтерактивне віртуальне спілкування зі своїми викладачами - тьюторами, і самостійно вирішують, коли вони готові здати віртуальний екзамен.

На думку багатьох спеціалістів у галузі освіти, дистанційне навчання є перспективним напрямом розвитку освітніх технологій у XXI сторіччі. Воно не замінить традиційне навчання, але створить більше можливостей для навчання. Саме життя підштовхує до розвитку прогресивних освітніх технологій.

Серед інтелектуальних технологій навчання, які застосовуються у відкритому інформаційно-освітньому середовищі, найбільшою популярністю у студентів користуються відкриті освітні онлайн-курси та інтерактивні соціальні сервіси, які дають змогу дистанційно навчатися в системі відкритої освіти, доступної в будь-який час і в будь-якому місці. Такі ресурси сприяють формуванню комунікативної і соціолінгвістичної компетенції, виступають додатковим інструментом розвитку цих компетенцій, є потужним мотивуючим фактором самоосвіти або самостійної підготовки до навчальних занять в освітній установі. Так, під час карантину багато університетів відкрили безоплатний доступ до своїх навчальних онлайн-курсів. Спеціальні сайти 3 онлайн-навчання запрошували усіх бажаючих приєднуватись до курсів із вивчення іноземних мов на різних рівнях, із культурологічною і просвітницькою тематикою. Наприклад, студенти факультету іноземної філології із задоволенням навчались і отримали сертифікати на пропонованих онлайн-платформах FutureLearn (https://www. futurelearn.com/), Coursera (https://www.coursera. org) та ін. В англомовній методичній літературі часто згадуються і такі навчальні інтернет-ресурси, як Hotlist, Treasure Hunt, Subject Sampler, Multimedia Scrapbook i Webquest [7].
Hotlist - це список корисних вебсайтів, що стосуються певної теми. Його досить просто створити, треба лише ввести ключове слово в пошукову систему Інтернету. Hotlist допомагає студентам скоротити час на пошук необхідної інформації.

Наприклад, Hotlist за темою "Easter Traditions From Around the Globe” («Традииї святкування Великодня в різних краӥнах світу»):

- https://www.freemalaysiatoday.com/category/ leisure/2020/04/12/5-fascinating-easter-traditionsfrom-around-the-globe/

- https://usafederalholidays.com/easter-holidays/ easter-traditions.

Multimedia Scrapbook - це своєрідна колекція мультимедійних ресурсів. На відміну від Hotlist, в Scrapbook містяться посилання не тільки на текстові сайти, а і на фотографії, аудіофайли та відеокліпи, графічну інформацію і дуже популярні віртуальні тури. Всі файли Scrapbook можуть бути легко завантажені студентами і використані як інформаційний та ілюстративний матеріал у процесі вивчення певної теми.

Наприклад, Scrapbook за темою "Easter Traditions From Around the Globe”.

Texts: https://learnenglishteens.britishcouncil.org/ uk-now/read-uk/easter

Video: https://www.youtube.com/watch?v= MQz2mF3jDMc

Pictures: https://www.pinterest.com/worldmarket/ easter-traditions/

Treasure Hunt (від гри «Полювання за скарбами», в якій гравцям надається низка підказок, щоб знайти схований приз). Цей ресурс також містить посилання на різні сайти за темою, що вивчається, але кожне $з$ посилань містить питання за змістом сайту. За допомогою цих питань викладач направляє пошукову діяльність студентів. Наприкінці студентам може бути задане узагальнююче питання на цілісне розуміння теми. Розгорнута відповідь на нього буде включати відповіді на попередні більш детальні питання за кожним із сайтів.

Наприклад, Treasure Hunt за темою "Easter Traditions From Around the Globe".

Introduction: For this class you'll need to learn about Easter meals and cooking in the UK. The web allows you to discover way more than you may have ever thought possible and is a great compliment to the materials found in the Student's book. Below there is a list of the questions about the topic of the lesson. Surf the links on this page to find answers to the questions.

Questions:

1. In English speaking countries, when should you traditionally decorate your eggs?

2. Where might a German family hang its Easter eggs? 
3. What do Easter bunnies symbolise? etc.

List of useful Internet resources to find the information on the topic:

- https://www.theguardian.com/commentisfree/ quiz/2012/apr/06/easter-around-the-world-quize Internet Resources/

- https://readymadepubquiz.com/easter-quizround-3-easter-around-the-world/

Subject Sampler наступний за складністю pecypc. Тут також містяться посилання на текстові та мультимедійні матеріали мережі Інтернет (фотографії, аудіо- та відеокліпи, графічна інформація). Після вивчення кожного аспекту теми учням необхідно відповісти на поставлені запитання, однак, на відміну від Treasure Hunt, за допомогою якого відбувається вивчення фактичного матеріалу, Subject Sampler спрямований на обговорення соціально загострених і дискусійних тем. Студентам необхідно не просто ознайомитися 3 матеріалом, але й висловити і аргументувати власну думку за темою дискусії.

Webquest - це найскладніший тип навчальних інтернет-ресурсів, який являє собою сценарій організації проєктної діяльності студентів із будьякої темі з використанням ресурсів інтернету. Він включає компоненти усіх попередніх ресурсів і передбачає проведення проєкту за участю всіх студентів.

Навчальні інтернет-ресурси (поряд із друкованими підручниками і навчальними посібниками) спрямовані на розвиток іншомовної комунікативної компетенції.

Hotlist, Treasure Hunt, Subject Sampler, Multimedia Scrapbook $i$ Webquest, безсумнівно, збагачують заняття $з$ іноземної мови. Складність матеріалу i його обсяг можуть змінюватись залежно від рівня володіння іноземною мовою, загального рівня розвитку інформаційної компетенції, інтересів і освітніх потреб студентів [9].

Узагальнюючи досвід онлайн-занять 3 англійської мови під час карантину, можна виділити певні проблеми, наприклад, відсутність очного спілкування між студентами та викладачами, якщо студент не мав змоги вийти у відеорежим спілкування. Виявилось, що не всі студенти були готовими до жорсткої самодисципліни, самостійності і самоконтроля у процесі онлайн-навчання. Хороша технічна оснащеність і доступ до якісного інтернету також був проблемою для певної категорії студентів. Однією з ключових проблем онлайн-навчання залишається проблема аутенти- фікації користувача під час перевірки знань, адже неможливо впевнено сказати, хто саме виконав завдання. Частково ця проблема вирішується установкою вебкамер, але з певних причин багато хто зі студентів не користувався такою можливістю.

До переваг дистанційної освіти можна зарахувати навчання в індивідуальному темпі, гнучкому режимі, комфортних умовах, тобто студент сам вибирає швидкість вивчення навчального матеріалу залежно від його особистих обставин і потреб, може самостійно планувати час, місце i тривалість занять. Також перевагою навчання в онлайн-режимі $\epsilon$ соціальна рівноправність, що означає рівні можливості отримання освіти незалежно від місця проживання, стану здоров'я, матеріальної забезпеченості студента. Досить важливо i те, що студенти мають змогу використовувати в освітньому процесі новітні досягнення інформаційних технологій.

Висновки. Таким чином, формування цифрової компетентності $\epsilon$ одним із важливіших чинників професійного самовдосконалення майбутніх вчителів іноземної мови, адже дає змогу швидко зорієнтуватися в бурхливому потоці змін у суспільстві. Навчальні інтернет-ресурси допомагають швидко знайти текстовий, графічний, аудіо- і відеоматеріал до теми заняття, організувати дискусію, проектну діяльність, створити сприятливі умови для реалізації інтелектуального потенціалу студентів. Для онлайн-навчання потрібно мати сильну мотивацію і самоорганізацію, адже дистанційне навчання може бути успішним тільки за умов сформованості таких якостей і умінь, як відповідальність, уважність, здатність працювати самостійно, систематично і наполегливо, уміння працювати в команді, уміння дослухатися до іншої точки зору водночас з умінням, у разі потреби, аргументовано відстоювати власну позицію. Удосконалення практичної підготовки студентів до майбутньої професійної діяльності посилює взаємодію вищої школи з ринками праці i допоможе вирішенню економічних, політичних i соціальних завдань, що стоять перед суспільством в епоху переходу до цифрової економіки. Сучасна модель освіти 3 елементами дистанційного навчання потребує подальших наукових досліджень у галузі методики дистанційного навчання іноземних мов, використання інноваційних технологій, які активізують пізнавальну діяльність студентів і сприяють прискоренню їх професійного становлення.

\section{Література}

1. Гончаренко С. Український педагогічний словник. Київ : Либідь, 1997. 366 с.

2. Каплінський В. Методика викладання у вищій школі. Київ : КНТ, 2019. 225 с.

3. Національна стратегія розвитку освіти в Україні на період до 2021 року. URL: http://zakon3.rada.gov.ua/ laws/show/344/2013. 
4. Фіцула М. Професійне самовдосконалення майбутніх фахівців. Педагогіка вищої школи : навч. посібник. Київ : Академвидав, 2010. С. 51-58.

5. Стрельченко Л.В. Розвиток інформаційно-комунікативної компетентності майбутніх викладачів англійської мови у Великій Британії. Педагогічні науки: теорія, історія, інноваційні технології. 2015. № 4 (48). C. 126-132.

6. Common European framework of reference for languages: learning, teaching, assessment. URL: $\mathrm{http} / / /$ www.coe.int/t/dg4/linguistic/Source/Framework_EN.pdf.

7. Hotlist, Treasure Hunt, Subject Sampler, Multimedia Scrapbook, Webquest. URL: http:/isco798.blogspot.com/.

8. Working the Web for Education. URL: https://tommarch.com/writings/theory/.

9. Creating web-based activities for learning. URL: http://faculty.augie.edu/ pchanavan/webactivities.htm.

\section{References}

1. Honcharenko S. Ukrainskyi pedahohichnyi slovnyk [Goncharenko S. Ukrainian pedagogical dictionary]. K. : Lybid, 1997. $366 \mathrm{~s}$.

2. Kaplinskyi V. Metodyka vykladannia u vyshchii shkoli [Kaplinsky V. Methods of teaching in higher school]. K. : KNT, 2019. $225 \mathrm{~s}$.

3. Natsionalna stratehiia rozvytku osvity v Ukraini na period do 2021 roku [National strategy for the development of education in Ukraine until 2021]. URL: http://zakon3.rada.gov.ua/laws/show/344/2013.

4. Fitsula M. Profesiine samovdoskonalennia maibutnikh fakhivtsiv : Pedahohika vyshchoi shkoly : navch. posib. [Fitsula M. Professional self-improvement of future professionals : Pedagogy of higher school: textbook]. K.: Akademvydav, 2010. S. 51-58.

5. Strelchenko L.V. Rozvytok informatsiino-komunikatyvnoi kompetentnosti maibutnikh vykladachiv anhliiskoi movy u Velykii Brytanii. Pedahohichni nauky: teoriia, istoriia, innovatsiini tekhnolohii. 2015. № 4 (48). S. 126-132. [Strelchenko LV. Development of information and communication competence of future English teachers in Great Britain. Pedagogical sciences: theory, history, innovative technologies. 2015. № 4 (48). P. 126-132].

6. Common European framework of reference for languages: learning, teaching, assessment. URL: http://www.coe.int/t/dg4/linguistic/Source/Framework_EN.pdf.

7. Hotlist, Treasure Hunt, Subject Sampler, Multimedia Scrapbook, Webquest. URL: http://isco798.blogspot.com/.

8. Working the Web for Education. URL: https://tommarch.com/writings/theory/.

9. Creating web-based activities for learning. URL: http://faculty.augie.edu/ pchanavan/webactivities.htm. 